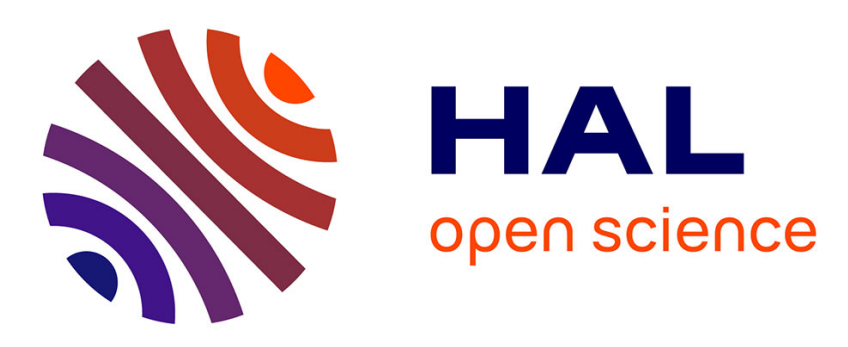

\title{
Analytical Determination of Phylloquinone (Vitamin K1) in Olive Oils. Comparison with Other Vegetable Oils
}

Catherine Rebufa, Jacques Artaud

\section{- To cite this version:}

Catherine Rebufa, Jacques Artaud. Analytical Determination of Phylloquinone (Vitamin K1) in Olive Oils. Comparison with Other Vegetable Oils. European Journal of Lipid Science and Technology, 2018, 120 (6), 10.1002/ejlt.201700527 . hal-01928770

\section{HAL Id: hal-01928770 \\ https://hal-amu.archives-ouvertes.fr/hal-01928770}

Submitted on 20 Nov 2018

HAL is a multi-disciplinary open access archive for the deposit and dissemination of scientific research documents, whether they are published or not. The documents may come from teaching and research institutions in France or abroad, or from public or private research centers.
L'archive ouverte pluridisciplinaire HAL, est destinée au dépôt et à la diffusion de documents scientifiques de niveau recherche, publiés ou non, émanant des établissements d'enseignement et de recherche français ou étrangers, des laboratoires publics ou privés.

\section{(c)(1)}

Distributed under a Creative Commons Attribution| 4.0 International License 


\title{
Analytical Determination of Phylloquinone (Vitamin K1) in Olive Oils. Comparison with Other Vegetable Oils
}

\author{
Catherine Rébufa* and Jacques Artaud
}

Olive oil is mainly consumed in the Mediterranean basin and is an important source of lipids, antioxidants, and vitamins. Vitamin $E$ (tocopherols) and phylloquinone (vitamin $K_{7}$ ), are present in oils. If vitamin $E$ is the subject of numerous studies, it is not the case for phylloquinone. The aim of this work is to uncover the latest advancements on phylloquinone contents in olive and vegetable oils. A bibliometric study, from Google Scholar and Web of Science databases, on the determination of phylloquinone content in vegetable oils made it possible to count a large number of scientific papers related to food matrices but few articles on olive and vegetable oils. The analysis of relevant works allows the comparison of the phylloquinone content of olive oils to the other vegetable oils. The different steps of oil sample preparation before their analysis are reviewed. A compilation of analytical conditions and methods is realized and it is be found that liquid chromatography with post reduction column and fluorescence detection is the technique most appropriate. On the basis of their phylloquinone content, two oil groups are highlighted; olive oil belongs to the oil groups (canola, soybean, pumkin, avocado, and cottonseed) having higher values $\left(60-348 \mu \mathrm{g} 100 \mathrm{~g}^{-1}\right)$ of phylloquinone. Pratical Application: Phylloquinone (or vitamin $\mathrm{K}_{1}$ ) content in vegetable oils and particularly in olive oils is little documented. Phylloquinone exists under $E$ and $\mathrm{Z}$ forms in oils. The recommended daily intake (for women and men) varies between 55 and $120 \mathrm{\mu g}$ day $^{-1}$ for patients without anticoagulant medication. The knowledge of the two isomers content in vegetable oils is important in nutrition and heath fields because only the $E$ isomer is bioactive.

have different cofactors (as the conversion of specific peptide-bound glutamate (Glu) residues to $\gamma$-carboxyglutamate (Gla)) or activities and multiple functions according to processes (absorption, transport, cellular uptake, tissue distribution, and turnover), developed in detail in four reviews. ${ }^{[1-4]}$ Adequate intake of vitamin $\mathrm{K}$ is recommended for all ages and gender people (infants, children, pregnant, and breastfeeding women and men); it ranges from 55 to $90 \mu \mathrm{g} \mathrm{day}^{-1}$ for adult women and 65-120 $\mathrm{g} \mathrm{day}^{-1}$ for adult men. ${ }^{[-6]}$ No tolerable upper limit has been defined. Nevertheless, the consumption of various dietary supplements or food rich on $\mathrm{PH}$ must be reduced when people take anticoagulant medication in order to avoid any adverse outcomes. ${ }^{[6]}$ The major dietary source of vitamin $\mathrm{K}$ is phylloquinone within the chloroplasts of green plants. ${ }^{[7]}$ Also, different phylloquinone databases from food matrix (in USA, UK, Netherlands, and Japan) have been published. ${ }^{[8-12]}$ These works showed that the $\mathrm{PH}$ intakes came largely from leafy vegetables (as Broccoli, cabbage, Perilla, spinach. . .) where its content varied between 113 and $400 \mu \mathrm{g} 100 \mathrm{~g}^{-1}$. $[9,13]$ Of course, this concentration range depended on cooking process and varietal type of vegetables. ${ }^{[14]}$ Various amounts of $\mathrm{PH}$ have been found in algae (green or purple laver,

\section{Introduction}

Vitamin K is part of fat-soluble vitamins such as vitamins A, D, and E but it is probably the one that has been the least studied. The term vitamin $\mathrm{K}$ is a generic name, which groups together several compounds having a 2-methyl 1-4-naphthoquinone ring. The natural forms of vitamin $\mathrm{K}$ (VK) comprise the phylloquinone $(\mathrm{PH})$ (or vitamin $\mathrm{K}_{1}, \mathrm{VK}_{1}$ ) of a vegetable origin and menaquinones MK-n (or vitamin $\mathrm{K}_{2}$ ) of animal origin or bacterial fermentation. Initially known for its role in haemostasis, these several molecular forms

Dr. C. Rébufa, Prof. J. Artaud

Aix Marseille Univ

Univ Avignon

CNRS, IRD, IMBE

BEC, F-13013 Marseille, France

E-mail: c.rebufa@univ-amu.fr konbu, hijiki, wakame...) (4-1385 $\left.\mu \mathrm{g} 100 \mathrm{~g}^{-1}\right),{ }^{[12,15]}$ in culinary herbs, dried, or fresh, (Basil, Marjoram, Parsley, Rosemary...)

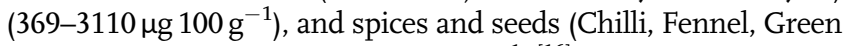
pepper, Safron...) (0.125-364 $\left.\mu \mathrm{g} 100 \mathrm{~g}^{-1}\right) \cdot{ }^{[16]}$ Variable PH content has been found in black or green tea leaves

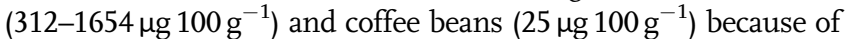
the variety, the storage, processing, harvesting and geographic origin but their brews are not an important source of this vitamin

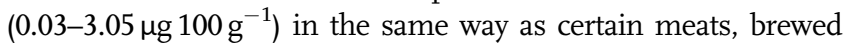
beverages, soft drink, and alcoholic beverages. ${ }^{[11,12,17]}$ Among the numerous feed habitually eaten by people, certain fats and oils showed an interested content of PH. PH content of margarines (defined as product containing not less than $80 \%$ fat and derived from vegetable oils) was depending on the varietal origin of the oils, margarine processing, and type of margarines (blended, hard, and

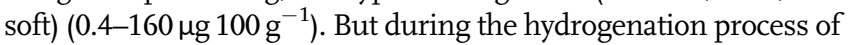
oil, part of the phylloquinone was transformed into $2^{\prime}$, $3^{\prime}$ dihydrophylloquinone, compound also analyzed in some 
works. ${ }^{[11,12,18-21]}$ Some mixed dishes contained moderates amounts of phylloquinone that were often attributable to the vegetable oils used in their preparation. Some vegetable oils such as soybean, cottonseed, rapeseed (canola), and olive were a recognized source of PH intakes. ${ }^{[8,11,12,18,19,22-24]}$ Concerning specifically olive oil, two vitamins were known as minor compounds, the phylloquinone and vitamin $\mathrm{E}$ (general term employed to designate tocopherols and tocotrienols, including $\alpha, \beta, \gamma$, and $\delta$ species). Several works have studied the vitamin E content in olive oil revealing that $\alpha$-tocopherol was the main compound but $\delta$-tocopherol et tocotrienols have not been detected in olive oil. ${ }^{[25,26]}$ On the other hand, phylloquinone has been the subject of few works because of the small quantities present in the olive oil and the difficulties of analyzes of this compound. This review presents the latest advancements on $\mathrm{PH}$ content in olive oils. The data come from a bibliometric study that addresses the problems of nomenclature, sampling, stability, analytical methods, and $\mathrm{PH}$ content in olive oils and compares them to $\mathrm{PH}$ content in vegetable oils.

\section{Historic Background}

Vitamin K was discovered incidentally, in the course of research on the metabolism of cholesterol, undertaken in 1929, by a Danish nutritional biochemist, Carl Peter Henrik Dam of the Polytechnic Institute of Copenhagen, Denmark. He studied the role of a low-fat diet on the chicks and noticed that it caused them to bleed. In 1935, he identified the vitamin responsible for coagulation and named it "Koagulation Vitamin." Also the letter K came from the German word "Koagulation." As early as 1936, an oily vitamin K was extracted from alfalfa by H. C. P. Dam, and in 1939, the American biochemist Edward Adelbert Doisy of the St. Louis University, Missouri, synthesized it and named it vitamin $K_{1}$ (phylloquinone). The Doisy group also isolated another form of vitamin from putrefied fish meal, another substance with antihemorrhagic activity which he baptized vitamin $\mathrm{K}_{2}$ and now known as menaquinone-6. In 1943, the Nobel Prize for Physiology or Medicine was awarded to C. P. H. Dam for his discovery of vitamin K and to E. A. Doisy, for his discovery of the chemical nature of vitamin K. A detailed historical background was made by Suttie. ${ }^{[27]}$

\section{Vitamin K Designations}

Numerous terms are used to describe the different forms of vitamins $\mathrm{K}$ in scientific literature and the most commonly encountered are not those derive from IUPAC nomenclature. In fact, vitamin $\mathrm{K}$ is the generic term of a group of fat-soluble vitamins of natural or synthetic origins, those the chemical structure has a common 2-methyl-1,4-naphthoquinone ring, but differs in the length and degree of saturation of their isoprenoid side chain at the 3-position. ${ }^{[1,28]}$ All the chemical compounds cited below are detailed in Table 1. In nature, this 3-substituent depends on the organism by which it is synthesized. Two natural forms of vitamin $\mathrm{K}$ have been isolated, phylloquinone (or vitamin $\mathrm{K}_{1}$ ) and menaquinones (or vitamin $\mathrm{K}_{2}$ ). The first one is the compound $\left[R-\left[R^{*}, R^{*}-(E)\right]\right]-2-m e t h y l-3-(3,7,11,15$-tetramethyl2-hexadecenyl)-1,4-naphthalenedione (Ia) (IUPAC; CAS number: 84-80-0, $\mathrm{C}_{31} \mathrm{H}_{46} \mathrm{O}_{2}$ ) which has a lateral chain which contains four isoprenoid units, three of which are reduced. The side chain (also called phytyl chain) with one double bond E (Ia, transisomer) or $\mathrm{Z}$ (Ib, cis-isomer) is the same phytyl side chain as in chlorophyll. The coexistence of $\mathrm{E}$ and $\mathrm{Z}$ isomers was highlighted by Cook et al. ${ }^{[20]}$ and Woollard et al. ${ }^{[29]}$ in vegetable oils with $\mathrm{Z}$ isomer content relatively high in opposite with those found in most foods. ${ }^{[5]} \mathrm{E}$ isomer is naturally found in all green plants and it is yellow oil soluble in fats (and insoluble in water). It is commonly designated as phylloquinone or 2-methyl-3-phytyl1,4-naphthoquinone, or vitamin $\mathrm{K}_{1}$, also $\mathrm{K}_{1(20)}$ because of the 20 carbon atoms of its phytyl chain linked on the position 3 on its naphthoquinone ring. Various synonyms are found in different articles as phytomenadione (used by The European Pharmacopoeia and occasionally found in the pharmaceutical and pharmacological literature), phytonadione (United States Pharmacopeia), phytylmenadione, 3-phytylmenadione, 2-methyl-3(3,7,11,15-tetramethyl-2-hexadecenyl)-1,4-naphthalenedione.

The second natural form groups together the multiprenyl menaquinones with a side chain of 20-60 carbon atoms and many unsaturated side chains. These compounds are soluble in fats, like vitamin $\mathrm{K}_{1}$. The menaquinone with $n$ isoprenoids units are commonly called vitamin $\mathrm{K}_{2(n)}$ and classified according to the number of prenyl units (3-methyl-but-2-en-1-yl); number being given as suffix: i.e., menaquinone- $n$ abbreviated MK- $n$ (II). ${ }^{[30]}$ Menaquinones only occur in foods of animal origin or foods altered by bacterial fermentation. Generally, microorganisms, including bacteria from the human intestine and other animal species, synthesized menaquinones containing from 4 to 13 isoprenoid units. Several authors ${ }^{[4,7,31]}$ reported that the origin of the menaquinone MK-4 (III) (also called vitamin $\mathrm{K}_{2(4)}$ or 2methyl-3-geranyl-geranyl-1,4-naphtoquinone, $\mathrm{C}_{31} \mathrm{H}_{40} \mathrm{O}_{2}$ ) was not bacterial but this compound was formed by a re-alkylation step from menadione (IV) present in animal feeds or was the product of tissue-specific conversion directly from dietary phylloquinone. Among the various synthetic forms of vitamin $\mathrm{K}$, one finds the parent compound, the 2-methyl-1,4-naphthoquinone (IV) (or menadione), also called vitamin $\mathrm{K}_{3}\left(\mathrm{C}_{11} \mathrm{H}_{8} \mathrm{O}_{2}\right)$, without side-chain, soluble in water, unlike the previous ones. This vitamin $\mathrm{K}_{3}$, as a provitamin, can be alkylated enzymatically to be converted into vitamin $\mathrm{K}_{2(4)}$ in animal tissues ${ }^{[32]}$ and has a biological activity 2-3 times greater than the vitamins $K_{1}$ and $K_{2}$. There are another synthetic forms of vitamin $\mathrm{K}$ as (i) menadiol (V) (formerly known as vitamin $\mathrm{K}_{4}$ or 2-methylnaphthalene-1,4diol or reduced menadione or dihydrovitamin $\mathrm{K}_{3}$ or vitamin $\mathrm{K}_{3} \mathrm{H}_{2}, \mathrm{C}_{11} \mathrm{H}_{10} \mathrm{O}_{2}$ ); (ii) the compound $2^{\prime}, 3^{\prime}$-dihydrovitamin $\mathrm{K}_{1}(\mathrm{VI})$ ( $\beta, \gamma$-dihydro vitamin $K_{1}$, or 2-methyl-3-(3,7,11,15-tetramethylhexadecyl)-1,4-naphthalenedione, $\mathrm{C}_{31} \mathrm{H}_{48} \mathrm{O}_{2}$ ), resulting of the reduction of phylloquinone side chain; (iii) the vitamin $\mathrm{K}_{1(25)}$ (VII) (or 2-methyl-3-(3,7,11,15,19-pentamethyl-2-eicosenyl)-1,4naphtalenedione, $\mathrm{C}_{36} \mathrm{H}_{56} \mathrm{O}_{2}$ ) produced by the substitution of a 25-carbon side chain on $\mathrm{C}_{3}$ carbon of menadione (IV); and (iiii) different vitamin $\mathrm{K}$ analogs with different length of the alkyl side-chain (VIII). ${ }^{[33]}$ Both synthetic forms are commonly used as internal standards in vitamin $\mathrm{K}$ analysis. The last form that can be evoked was the one form after a $\mathrm{PH}$ derivatization step (reduction) to make it detectable: the phyllohydroquinone (IX) (or hydroquinone or dihydrovitamin $\mathrm{K}_{1}$ or 2-methyl-3[(2E,7R,11R)-3,7,11,15-tetramethylhexadec-2-en-1-yl]naphthalene-1,4-diol). 
Table 1. Nomenclature and structure of Vitamin K.

\begin{tabular}{|c|c|c|c|c|}
\hline Compounds & Synonym names & $\begin{array}{l}\text { Molecular } \\
\text { formulae }\end{array}$ & Structural formulae & Origin \\
\hline (la) & $\begin{array}{l}\text { Phylloquinone. vitamin } K_{1}, 2 \text {-methyl-3-phytyl-1,4- } \\
\text { naphtoquinone. }\left[R-\left[R^{a)}, R^{a)}-(E)\right]-2 \text {-methyl-3- }\right. \\
(3,7,11,15 \text {-tetramethyl-2- hexadecenyl)-1, } \\
\text { 4-naphthalenedione }\end{array}$ & $\begin{array}{l}\mathrm{C}_{31} \mathrm{H}_{46} \mathrm{O}_{2} \\
\text { (trans) }\end{array}$ & & Vegetal \\
\hline (lb) & $\begin{array}{l}\text { Phylloquinone, vitamin } \mathrm{K}_{1}, 2 \text {-methyl- 3-phytyl-1,4- } \\
\text { naphtoquinone, }\left[\mathrm{R}-\left[\mathrm{R}^{*}, \mathrm{R}^{*} \text {-(Z)]-2-methyl-3- }\right.\right. \\
(3,7,11,15 \text {-tetramethyl-2-hexadecenyl)- } \\
\text { 1,4-naphthalenedione }\end{array}$ & $\begin{array}{c}\mathrm{C}_{31} \mathrm{H}_{46} \mathrm{O}_{2} \\
\text { (cis) }\end{array}$ & & Vegetal \\
\hline$(I I)^{a)}$ & Vitamins $\mathrm{K}_{2(\mathrm{n})}$, menaquinone MK-n & & & Microbial \\
\hline$(\mathrm{III})^{\mathrm{a})}$ & $\begin{array}{l}\text { Menaquinone (MK-4), vitamin } \mathrm{K}_{2(\mathrm{n})} \\
\text { 2-methyl-3-geranygeranyl-1,4-naphtoquinone }\end{array}$ & $\mathrm{C}_{31} \mathrm{H}_{40} \mathrm{O}_{2}$ & & Microbial \\
\hline (IV) & $\begin{array}{l}\text { Menadione, 2-methyl-1,4-naphtoquinone, } \\
\text { vitamin } \mathrm{K}_{3}\end{array}$ & $\mathrm{C}_{11} \mathrm{H}_{8} \mathrm{O}_{2}$ & & Synthetic \\
\hline (V) & $\begin{array}{l}\text { Menadiol vitamin } \mathrm{K}_{4} \text {, 2-methylnaphthalene-1,4-diol, } \\
\text { reduced menadione, dihydrovitamin } \mathrm{K}_{3} \text {. Vitamin } \mathrm{K}_{3} \mathrm{H}_{2}\end{array}$ & $\mathrm{C}_{11} \mathrm{H}_{10} \mathrm{O}_{2}$ & & Synthetic \\
\hline$(\mathrm{VI})^{\mathrm{a})}$ & $\begin{array}{c}\text { 2', } 3^{\prime} \text {-dihydrovitamin } \mathrm{K}_{1}, \beta, \gamma \text {-dihydro vitamin } \mathrm{K}_{1} \text {, } \\
\text { 2-methyl-3-(3,7,11,15-tetramethylhexadecyl)-1, } \\
\text { 4-naphthalenedione }\end{array}$ & $\mathrm{C}_{31} \mathrm{H}_{48} \mathrm{O}_{2}$ & & Synthetic \\
\hline$(\mathrm{VIII})^{\mathrm{a})}$ & $\begin{array}{c}\mathrm{K}_{1(25)} \text {, 2-methyl-3-(3,7,11,15, 19-pentamethyl-2- } \\
\text { eieosenyl)-1,4-naphthalenedione }\end{array}$ & $\mathrm{C}_{36} \mathrm{H}_{56} \mathrm{O}_{2}$ & & Synthetic \\
\hline$(\mathrm{VIII})^{\mathrm{a})}$ & $\begin{array}{l}\text { Vitamin } \mathrm{K} \text { analogs with different } \\
\text { length of the alkyl side-chain }\end{array}$ & & & Synthetic \\
\hline$(I X)^{a)}$ & $\begin{array}{c}\text { Phyllohydroquinone, hydroquinone, } \\
\text { dihydrovitamin } \mathrm{K}_{1}, 2 \text {-methyl-3- }[(2 \mathrm{E}, 7 \mathrm{R}, \\
11 \mathrm{R})-3,7,11,15 \text {-tetramethylhexadec-2-en-l-yl] } \\
\text { naphthalene-1,4-diol }\end{array}$ & $\mathrm{C}_{31} \mathrm{H}_{42} \mathrm{O}_{2}$ & & Synthetic \\
\hline
\end{tabular}

a) Internal or external standards.

\section{Bibliometric Study}

Searches in the Web of Science Core Collection databases (WoS) and Google Scholar (GS) web have been done between 1985 and June 2017 using different keywords and combination of them in the title of the articles. The terms edible, vegetable, or olive have been used to characterize oils while the synonyms vitamin $K_{1}$ and phylloquinone have been employed to restrict the study only to the compound of interest. This research also focused on $\mathrm{PH}$ quantification methods based on Gas Chromatography (GC) and High Pressure Liquid Chromatography (HPLC). Searches in WoS database have been performed for TOPIC ("edible oil*" or "vegetable oil*" or "olive oil*") AND TOPIC ("vitamin K1" or phylloquinone) AND TOPIC (HPLC or GC). A similar search was realized with $\mathrm{GS}$ tool by also performing an advanced search for the exact expression in quotation marks throughout the entire document. The methodology of this bibliometric study and the results of the search strings used in the two sources of information were synthetized on a graphical representation (Figure 1). The first remark was that all of these researches showed that the results were very different from one database to another. Bibliographic references were more numerous with GS tool because it provided broader coverage for most disciplines. It was criticized that its coverage was heterogeneous and poorly informed, including low quality "publications" such as blogs or magazine articles mixing academic and non-academic sources. 


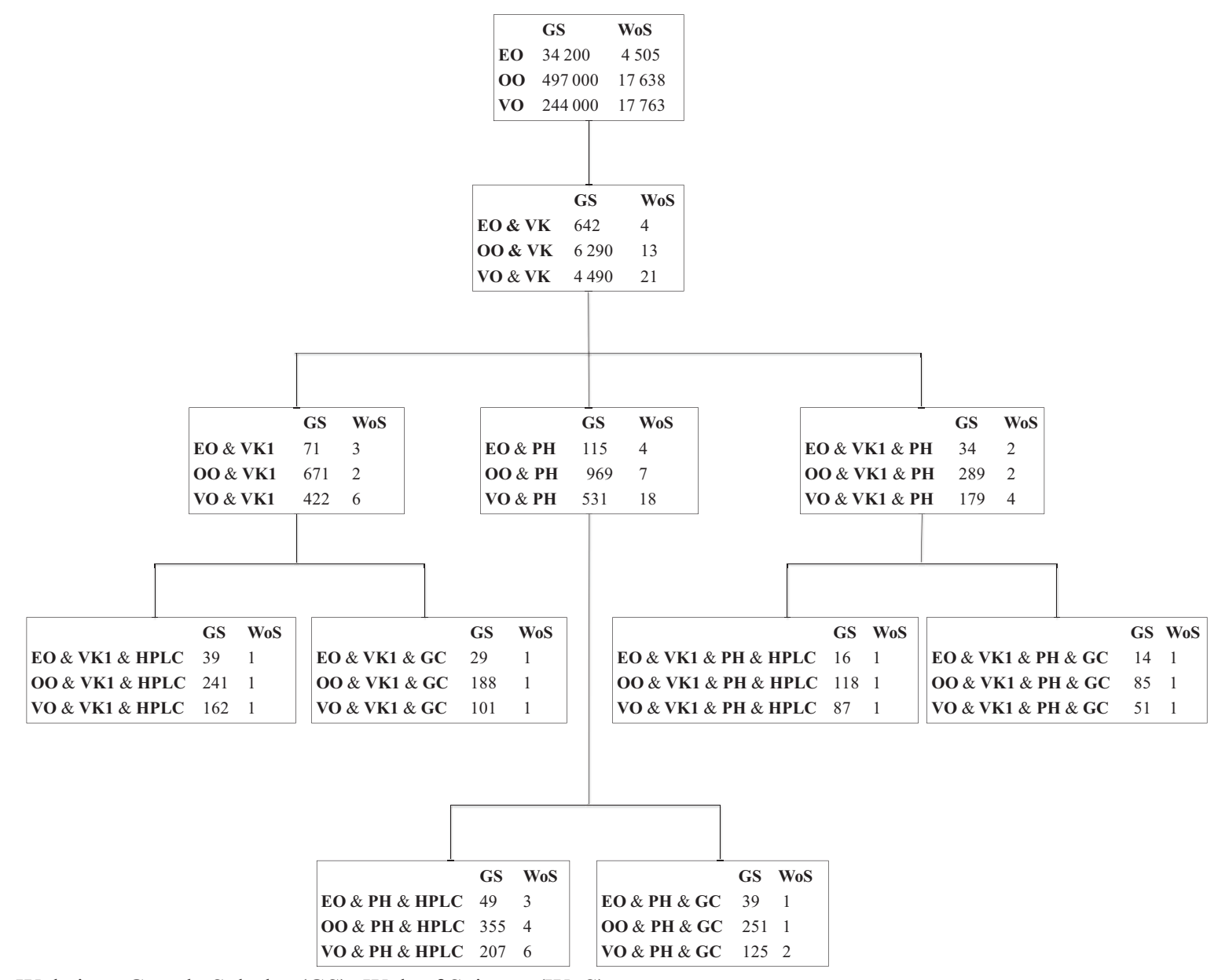

Websites: Google Scholar (GS); Web of Science (WoS)

Topics: EO: "edible oil*”; OO: "olive oil*”; PH: phylloquinone; VO: "vegetable oil*”; VK: "vitamin K"; VK1: "vitamin K1"

Figure 1. Graphical representation of bibliometric search (articles number) on the determination of PH content in vegetable oils. Websites: GS, Google Scholar; WoS, Web of Science. Topics: EO, "edible oil*"; OO, "olive oil*"; PH, phylloquinone; VO, "vegetable oil"”; VK, "vitamin K"; VK1, "vitamin K1".

Moreover, GS engine found a large number of duplicate papers. The typology of publications did not follow the same logic for WoS model which used a selection of papers and multidisciplinarity, thereby restraining its coverage. ${ }^{[34,35]}$ However, the search with the specific term "olive oil*" generated a greater number of publications that the global expressions as "edible and vegetable oil ${ }^{*}$ that it showed the importance of this food matrix and the extent of the fields in which olive oil was studied. Through the combination of the terms relating to oil with the synonyms of vitamin $\mathrm{K}_{1}$, the number of publications decreased rapidly, it was to highlight that word "phylloquinone" appeared more often in the title than "vitamin K1" and some authors used both terms for more precision. By using an additional search criterion as the analytical technique used for the determination of phylloquinone content, it appeared that the publications using HPLC were more numerous than those dealing with GC. The results found by the WoS model were limited and often identical with a different combination of keywords. Regarding in details the publications number found each year from 2000 to 2016
(Figure 2), it appeared that the numbers of papers quoting the combined keywords "vitamin K-olive oil" "or "vitamin K1-olive oil" or "phylloquinone-olive oil ${ }^{*}$ " increased regularly between the years 2000 and 2012, then the interest to study vitamin $\mathrm{K}$ has grown importantly after the year 2012. The term "phylloquinone" was more used than the expression "vitamin K1" in the different works during these last years. Among the different researches listed in Figure 1, 78 scientific papers showed an interest for the PH study in different fields (medical, food...), including only 25 articles, which treated the $\mathrm{PH}$ content in vegetable or edible oils and finally, only 20 publications have reported results on olive oil specifically. Nevertheless, the olive oil data extracted from these 20 publications were often repetitions of some particular studies. It was the case of Booth et al. publications in 1993,1998 , and $2012^{[3,7,8]}$ and the review of Eitenmiller et al. ${ }^{[5]}$ Furthermore, Booth and Ferland were coauthors as well as Piironen and Koivu. So, few PH data were available on olive oil because only 13 scientific articles were retained. ${ }^{[10-12,15,16,18,19,22,29,36-39]}$ This bibliometric approach 

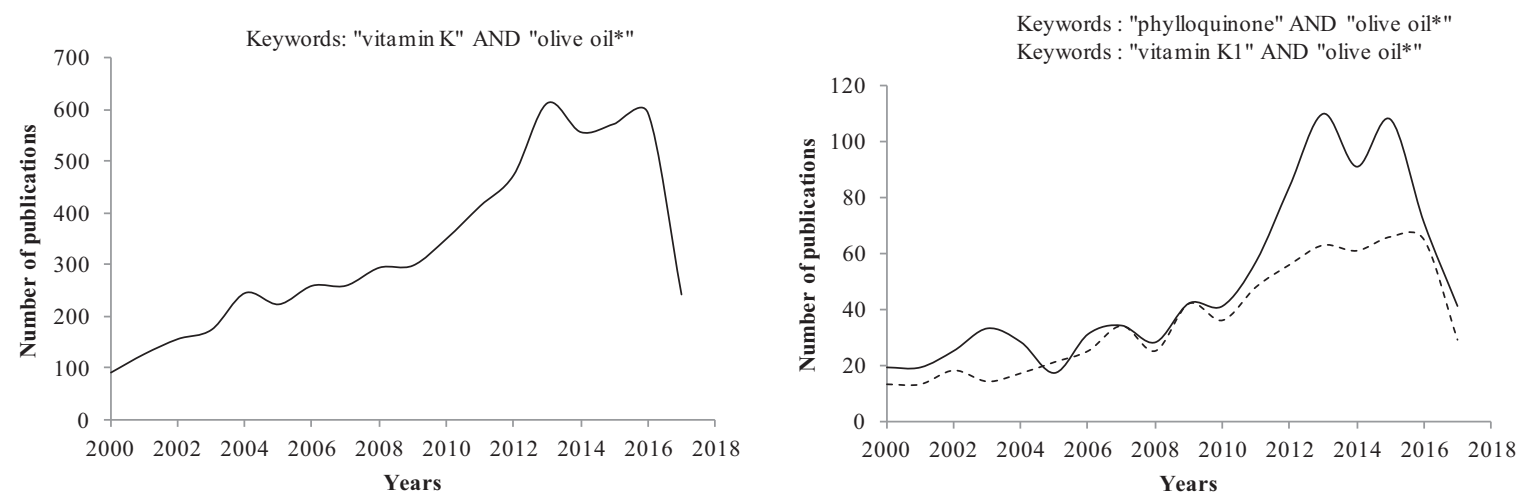

Figure 2. Temporal evolution of publication number cited by Google Scholar tool versus used keywords for the bibliometric search.

showed that the search using title or keywords converged with difficulty toward the target because the choice of keywords did not always reflect the publications content. So, among the 119 keywords highlighted from the 78 papers, the terms "phylloquinone" and "vitamin K" were used most often (23 times), "vitamin(s)" for five times, "fat soluble vitamin (s)" for four times, "HPLC" for 10 times, "vegetable oil(s)" for four times against two times for "olive oil." Often, data for edible oils have been found in publications used general words as "food," "food composition," or "food analysis" and "fat soluble vitamins" as keywords. It showed that a correct use of keywords required learning and that all people did not understand the keyword's notion in the same way. The difficulty was that the formal treatment of the data by the computers was different of the human way of thinking.

\section{Olive Oil Sampling}

One of the main difficulties encountered in reading the published works on olive oils was the lack of precision on the geographical or varietal samples origins, their conditioning, storage conditions, and storage time. However, it was known that these parameters had a great influence on the chemical composition of olive oils. In papers relating the $\mathrm{PH}$ content, olive oils were mainly purchased in local markets without information on their quality (extra virgin, virgin, or ordinary virgin) and their varietal origins. Only the authors, Zakhama et al. ${ }^{[38]}$ stated that their sampling were virgin olive oils of the two main Tunisian varieties (Chemlali and Chétoui), coming from a continuous industrial production system. In the case of refined olive oils, samples were procured from a pool of global suppliers of the food industry. ${ }^{[39]}$

\section{Phylloquinone Stability}

There were few studies that discussed the PH stability in food matrices when processing samples. $\mathrm{PH}$ content quantified in vegetable oils was relatively stable to processing mode (cold pressed or normal pressed olives) ${ }^{[22]}$ or was degraded slowly in presence of oxygen. ${ }^{[40]}$ It decreased slightly but significantly (15\% loss) after heating at temperatures of $185-190^{\circ} \mathrm{C}^{[22]}$ but the $\mathrm{PH}$ stability was not known during deodorization process realized at about $250^{\circ} \mathrm{C}$ for refined oils. On the opposite, Fanali et al. ${ }^{[41]}$ reported in their review on analytical techniques for fatsoluble vitamins that $\mathrm{PH}$ was stable to heat and oxygen. Moussa et al. ${ }^{[42]}$ determined $\mathrm{PH}$ concentration in intravenous fat emulsions and soybean oils and found variability in $\mathrm{PH}$ content that they assigned to the nature of the preparation, the producer and the production batch. PH was extremely sensitive to fluorescent light and daylight and was rapidly destroyed (46-59\% and $87-94 \%$ loss respectively after 2 days exposure for some vegetable oils) ${ }^{[22]}$ and $\mathrm{PH}$ into soybean oil was not detected after $48 \mathrm{~h}$ of exposure daylight; ${ }^{[42]}$ also it was necessary to work in subdued light when foods were being analyzed. In addition, E (trans-) isomer of PH could be transformed in Z (cis-) isomer under light action. ${ }^{[43,44]}$ In addition, $\mathrm{PH}$ was unstable in acidic or alkaline media. So, hot saponification, which can be used for individual and simultaneous extraction of vitamins $\mathrm{A}, \mathrm{D}$, and $\mathrm{E}$, is not advisable for vitamin $\mathrm{K}_{1} \cdot{ }^{[41]}$ This instability to alkalinity prohibited the use of saponification for olive oil sample extraction and led to extensive research to develop sample cleanup procedures to overcome insufficiencies of ultra violet detection for liquid chromatography methodology. ${ }^{[5]}$ A cold saponification have been developed in the dark at room temperature, ${ }^{[45,46]}$ using a minimum quantity of alkalis $(\mathrm{KOH}$ or $\mathrm{K}_{2} \mathrm{CO}_{3}$ ) with long reaction time in order to extract different nutrients and vitamins ( $\mathrm{K}_{1}, \mathrm{MK}-4$, and MK-7) from animal and human milk. Extraction yields were between $54 \%$ for the MK-4 vitamin and $100 \%$ for the other compounds. In addition, Fauler et al. ${ }^{[1]}$ pushed further the hypersensitivity of vitamin $\mathrm{K}$ towards the strong alkalies by advocating removing traces of detergents from washed glasses (intensive wash and glasses heating above $\left.500^{\circ} \mathrm{C}\right)$.

\section{Olive and Vegetable Oil Samples Preparation and Purification}

The low PH content in vegetable oils required a sample preparation prior to its quantitative analysis to avoid interferences with other compounds. The different steps of sample preparation were often done under subdued daylight ${ }^{[19,21,29,37,47]}$ because the $\mathrm{PH}$ was rapidly destroyed by both daylight and fluorescent light. ${ }^{[22]}$ The quantitative analysis of $\mathrm{PH}$ was performed using an internal addition standard method as well 
as internal or external standard methods. Internal standards (2',3'dihydrophylloquinone, menaquinone-4, $\mathrm{K}_{1(25)},{ }^{2} \mathrm{H}_{4}$-phylloquinone) were added to sample prior to its preparation and whose choice depended on the detection technique. Among these standard compounds, the most used was $2^{\prime}, 3^{\prime}$ dihydrophylloquinone while $\mathrm{PH}$ was used according to a standard addition method ${ }^{[20,36,42,48]}$ or as an external standard. ${ }^{[29]}$ Gao and Ackman $^{[23]}$ advocated an internal standard method that was much faster and more accurate than an external standard or a standard addition method. In the literature, different extraction methods have been used to obtain the PH from vegetable oils. In certain experimental procedures, an enzymatic hydroly$\operatorname{sis}^{[20,23,29,48]}$ or a saponification of oil ${ }^{[38]}$ were performed in a first step, but more frequently a direct oil solubilization was made in organic solvent as hexane $\mathrm{e}^{[12,18,22,36,37]}$ or solvent mixture (acetone/chloroform). ${ }^{[39]}$ For Peterson et al. ${ }^{[18]}$ oils were soluble in hexane so no extraction was necessary. The enzymatic digestion was carried on $0.25-0.50 \mathrm{~g}$ of oil sample using $1.00-1.25 \mathrm{~g}$ of lipase in $5-100 \mathrm{~mL}$ of phosphate buffer. Oil sample was incubated at $37^{\circ} \mathrm{C}$ with vigorous stirring or in a sonicator bath during $1.5-4 \mathrm{H}$ to ensure complete lipids hydrolysis. Thin-layer chromatography was used once time to verify the effectiveness of lipase digestion. The oil saponification (realized with $\mathrm{KOH}$ at $80 \%$ for $10 \mathrm{~min}$ at $80^{\circ} \mathrm{C}$ ) was rarely used $^{[38]}$ because of the instability of $\mathrm{PH}$ in basic medium. ${ }^{[5,41]}$ Then, oil samples have been generally purified prior to chromatographic analysis to remove lipids that may interfere when detecting PH. This purification was often realised on a Sep-Pak (SPE) silica cartridge $\mathrm{e}^{[12,18,22,23,39,42,49]}$ and little on alumina column ${ }^{[48]}$ and sometimes by semi preparative HPLC on $\mu$ Porasil column. ${ }^{[19,21,37]}$ The SPE extraction with silica cartridge was generally conducted in four steps: (i) a conditioning of the stationary phase by a wash of hexane or a mixture or hexane/diethyl ether $(96: 4, \mathrm{v} / \mathrm{v})$; (ii) a loading of the sample frequently dissolved in hexane; (iii) washing (s) of the cartridge with hexane to eliminate the less polar lipids and the hydrocarbons; and (iv) and finally elution of the fraction containing $\mathrm{PH}$ with hexane/diethyl ether $(96: 4, \mathrm{v} / \mathrm{v})$ or methanol/2-propanol/n-hexane (95:2.5:2.5, v/v/v) or hexane/ diisopropyl ether $(90: 10, \mathrm{v} / \mathrm{v})$. In one case ${ }^{[18]}$ oil samples were further processed by SPE C18 columns. When purification was performed with a semi preparative HPLC, a mobile phase with hexane containing $1 \%$ diethyl ether was used. In some works, the sample purification was performed by washing the hexane extract with polar solvents (methanol/water or water only). ${ }^{[38,47]}$ However, Cook et al. ${ }^{[20]}$ centrifuged their hexanic sample, which they then filtered through a $0.45 \mu \mathrm{m}$ glass microfiber filter. Figure 3 summarizes the different steps, identified in the articles (cited references), for the preparation and the purification of olive oil samples before their chromatographic analysis. Concerning the validation of these different extraction methods, parameters as recovery, precision (repeatability and reproducibility), linearity and specificity (peak purity), should have been provided as Kim et al. ${ }^{[50]}$ did it for the determination of $\mathrm{PH}$ content in legumes and nuts. Few authors specified the recovery of their extraction method. When a standard addition method was used, the authors made it clear that the recovery was calculated as the percent difference between the PH quantity recovered from the spiked and non spiked samples divided by the quantity of the phylloquinone added (spiked). ${ }^{[2,36,42,48]}$ Results were difficult to compare because they were not all related to olive oils but to different vegetable oils or margarines and the HPLC detector was not the same. However, the recovery range was $82-100 \%$ for the enzymatic method and $85-99 \%$ for the extraction way. With the same experimental conditions for the $\mathrm{PH}$ detection, ${ }^{[20]}$ the recovery range of trans-vitamin $\mathrm{K}_{1}$ was 93-99\% with the extraction method and 82-100\% after an enzymatic procedure for a vegetable oil blend (soybean partially hydrogenated and buttermilk). The use of internal standard ( $\mathrm{K}_{1}$ (25); 2',3'-dihydrophylloquinone; MK-4) for different oil samples and analytical detectors led to a recovery range of $86-103 \%$ for an enzymatic process ${ }^{[23,29]}$ and $55-100 \%$ for the extraction method. ${ }^{[18,19,21,22,36,37,42]}$ In light of these results, the widely used method was the solubilization of oil samples in hexane before purification with a Sep-Pak. This extraction mode, simple, rapid, effective, and automatizable, was recommended for extracting and concentrating the compound of interest before a chromatographic analysis.

\section{Analytical Techniques}

Various reviews on analysis methods of phylloquinone in food have been published in the past and are cited by Fauler et al. ${ }^{[1]}$ and Etienmiller et al. ${ }^{[5]}$ Thin layer chromatography (TLC) was the first chromatographic technique used for PH analysis. However, HPLC has replaced TLC because of its low sensitivity and the difficulty of quantifying small amounts of $\mathrm{PH}$ in food matrices. GC was not used frequently because of low volatility of $\mathrm{PH}$ which required high analysis temperatures $\left(\approx 300^{\circ} \mathrm{C}\right)$ leading to a possible degradation of phylloquinone in the chromatographic system. $^{[1]}$ To avoid a non-negligible degree of $\mathrm{PH}$ degradation during GC analysis, Fauler et al. ${ }^{[1]}$ advocated a reductive acylation in presence of zinc dust, heptafluorobutyric anhydride, and heptafluorobutyric acid in hexane solution. According to the works of Osman and Hannestad, ${ }^{[51]}$ an intramolecular rearrangement (a shift of the $\beta, \gamma$-double bond on the phytyl side chain toward the ring) could be possible when $\mathrm{PH}$ was analyzed in ethanol solution by GC.

HPLC was currently the most widely used technique for $\mathrm{PH}$ quantification with the help of different detectors allowing a detection of $\mathrm{PH}$ or its derivative homologues. Analytical methods available for the $\mathrm{PH}$ analysis in olive and vegetable oils were resumed in Table 2 and 3 respectively. Most of listed works was based on a reversed phase HPLC with octadecylsilane-bonded C18 phase or much less frequently with triacontyl-bonded C30 phase and seldom on normal-phase HPLC (silica). Little differences were observed on column characteristics (length or diameter) and no capillary columns were used as it was done for some food applications. The interest of using a C30 phase was to make it possible the separation of the $\mathrm{PH}$ isomers $\mathrm{E}$ and $\mathrm{Z}$ unlike $\mathrm{C} 18$ phase. ${ }^{[20,29]}$ The ability to separate $\mathrm{PH}$ isomers and to quantify the $\mathrm{E}$ form accurately is very important because $\mathrm{E}$ isomer is the biological active form of $\mathrm{PH}$ while $\mathrm{Z}$ isomer is an inactive form. ${ }^{[52]}$ Also, $\mathrm{E}$ isomer content measured the true nutritional value of $\mathrm{PH} .{ }^{[29]}$ Normal phase HPLC column allowed to separate $\mathrm{E}$ and $\mathrm{Z}$ isomers but its implementation was difficult which explained its lack of use in routine analyses. ${ }^{[4,53]}$ Only one 


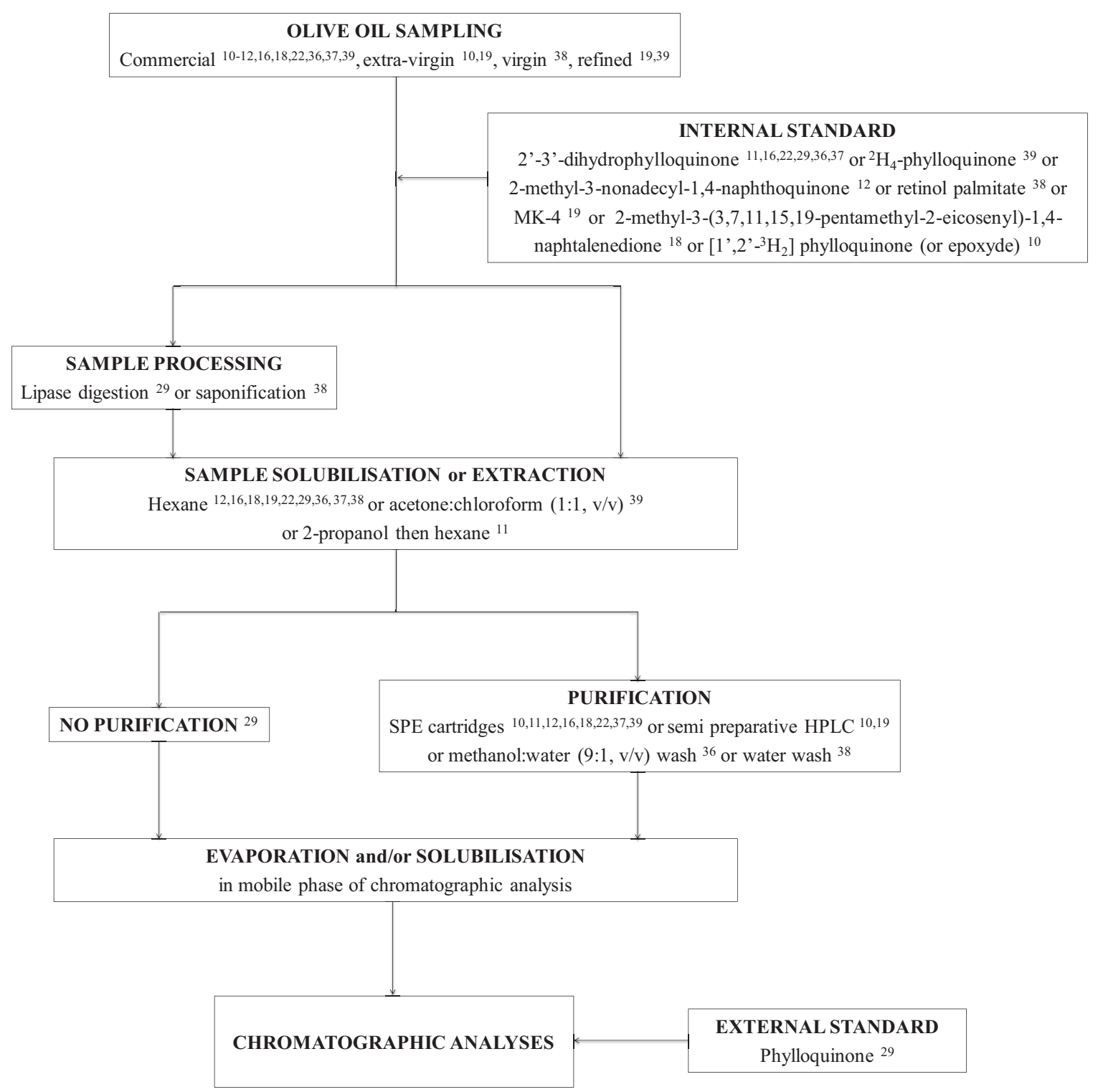

Figure 3. Different procedures of olive oil sample preparation for the $\mathrm{PH}$ quantification.

author $^{[39]}$ used a normal phase, a Hypersil silica column to quantify fat-soluble vitamins, including phylloquinone. In his review, Fanali et al. ${ }^{[41]}$ reported that normal phase column could tolerate relatively high loads of lipid material, easily removed from the column by non-polar mobile phase because of their low adsorption.

The nature of the mobile phase depended on the detection system used: Ultra Violet (UV), electrochemical, fluorescence, and mass spectrometry. Non-aqueous solvents were used with UV detection. Three studies reported PH quantification in oils using UV detection ${ }^{[37,38,48]}$ despite the low selectivity and sensibility of this detector. Because of the low value of $\mathrm{PH}$ molar absorptivity $\left(\varepsilon=19.900 \mathrm{~L} \mathrm{~mol}^{-1} \mathrm{~cm}^{-1}\right.$ at $\left.248 \mathrm{~nm}\right),{ }^{[1]}$ the detection limits were high with UV detection. In addition, despite the purification of oil sample, residual lipids could show an absorbance at the detection wavelength and distorted the $\mathrm{PH}$ quantification. Careri et al. ${ }^{[54]}$ highlighted this problem by working in vegetable samples. A mobile phase composed with methanol and sodium acetate buffer was used with an electrochemical detector operating in the redox mode using two electrodes to overcome the drawbacks of one electrode used in amperometric detection (oxygen traces, electrode passivation...). A first electrode reduced phylloquinone in phyllohydroquinone while the second one oxidized again the formed product. An application of this technique for $\mathrm{PH}$ detection in rat liver reported that electrochemical detector was found to be superior in terms of sensibility and selectivity to the UV detector. ${ }^{[55]}$ A comparative study of the sensitivities of a single carbon electrode cell (reductive mode) and a dual porous graphite electrode cell (redox mode) was realized to quantify endogenous phylloquinone in plasma and confirmed the superiority of the dual-electrode detector. ${ }^{[56]}$ In the case of oil 
Table 2. Analytical procedures for $\mathrm{PH}$ determination $\left(\mu \mathrm{g} 100 \mathrm{~g}^{-1}\right.$ or ${ }^{*} \mu \mathrm{g} 100 \mathrm{~mL}^{-1}$ ) in olive oil samples.

\begin{tabular}{|c|c|c|c|c|c|c|c|}
\hline References & Origins & $\mathrm{N}$ & Columns & Mobile phase-flow rate & Reduction & Detector & $\begin{array}{l}\text { Phylloquinone } \\
\text { content }\end{array}$ \\
\hline${ }^{[8]}$ from ${ }^{[15]}$ & Unspecified & 1 & Unspecified & Unspecified & Unspecified & Unspecified & 42 \\
\hline [10] & ExtraVirgin & 2 & Reversed phase $\mathrm{C} 18$ & Unspecified & No & $\begin{array}{l}\text { Electrochemical redox } \\
\text { mode; UV }\end{array}$ & $74 ; 85$ \\
\hline & Cheaper oil & 1 & & & & & 30 \\
\hline [12] & Commercial & 1 & $\begin{array}{c}250 \times 4.6 \mathrm{~mm} \text { id, } \\
5 \mu \mathrm{m}, \text { Capcell Pak C18 } \\
\text { UG } 120 \\
\text { Shiseido, } 35^{\circ} \mathrm{C}\end{array}$ & $\begin{array}{l}\mathrm{CH}_{3} \mathrm{OH} / \mathrm{CH}_{3} \mathrm{CH}_{2} \mathrm{OH}, \\
95 / 5(\mathrm{v} / \mathrm{v}), 1 \mathrm{~mL} \mathrm{~min}^{-1}\end{array}$ & $\begin{array}{l}\text { Platinum reduction } \\
\text { column } \\
(15 \times 4.0 \mathrm{~mm})\end{array}$ & $\begin{array}{c}\text { Fluorescence RF-10A } 10 \mathrm{~L} \\
\text { Shimadzu, } \lambda \text { ex.: } 240 \mathrm{~nm} \text {, } \\
\lambda e m .: 430 \mathrm{~nm}\end{array}$ & $63 \pm 11(\mathrm{SD})$ \\
\hline [16] & Commercial & 1 & $\begin{array}{l}150 \times 4.6 \mathrm{~mm} \text { id, } \\
3 \mu \mathrm{m}, \mathrm{C} 18 \text { Hypersil, } \\
\text { Thermo Scientific }\end{array}$ & $\begin{array}{c}\mathrm{CH}_{3} \mathrm{OH}, \mathrm{CH}_{3} \mathrm{CN}, \mathrm{H}_{2} \mathrm{O} \\
94,5 / 5 / 0,5(\mathrm{v} / \mathrm{v} / \mathrm{v}) ; \text { isocratic }\end{array}$ & $\begin{array}{l}\text { Postcolumn with dry } \\
\text { powder } \mathrm{Zn} \\
(20 \times 3.9 \mathrm{~mm})\end{array}$ & 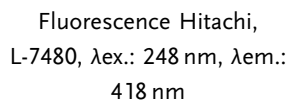 & $65.1(3.5 \% \mathrm{CV})$ \\
\hline [18] & Commercial & 2 & $\begin{array}{l}150 \times 3 \mathrm{~mm} \text { id, } 5 \mu \mathrm{m} \\
\text { BDS Hypersil C } 18 \\
\text { Keystone }\end{array}$ & $\begin{array}{c}\text { Solvent } \mathrm{A}: \mathrm{CH}_{3} \mathrm{OH}+\left(10 \mathrm{mM} \mathrm{ZnCl}_{2}\right. \\
\left.5 \mathrm{mM} \mathrm{CH}{ }_{3} \mathrm{COOH}, 5 \mathrm{mM} \mathrm{CH}_{3} \mathrm{COONa}\right) \\
(1 \mathrm{~L}) \text {; Solvent B: } \mathrm{CH}_{2} \mathrm{Cl}_{2} \text {; gradient }\end{array}$ & $\begin{array}{l}\text { Postcolumn with dry } \\
\text { powder } \mathrm{Zn} \\
(50 \times 2.0 \mathrm{~mm} \\
200 \text { mesh })\end{array}$ & $\begin{array}{l}\text { Fluorescence Shimadzu, } \\
\lambda \text { ex.: } 244 \mathrm{~nm}, \lambda e m .: 430 \mathrm{~nm}\end{array}$ & $\begin{array}{l}50.1 ; 70.3 \\
(14.3) \mathrm{SD} \\
\text { mean } 60.2\end{array}$ \\
\hline \multirow[t]{2}{*}{ [19] } & $\begin{array}{l}\text { Italy extra } \\
\text { virgin }\end{array}$ & 2 & $\begin{array}{l}250 \times 4.6 \mathrm{~mm} \text { id } \\
5 \mu \mathrm{m}, \mathrm{Vydac}\end{array}$ & $95 \% \mathrm{CH}_{3} \mathrm{OH}-0,05 \mathrm{CH}_{3} \mathrm{COONa}$ & No & $\begin{array}{l}\text { Electrochemical, dual } \\
\text { electrode }\end{array}$ & $\begin{array}{l}44 \pm 3(S D) \\
50 \pm 4(S D) \\
\text { mean } 50.0\end{array}$ \\
\hline & Refined & 2 & 201 TP54, Hesperia & $\mathrm{pH} 3 ; 1 \mathrm{~mL} \min ^{-1}$ & & $\begin{array}{l}\text { Analytical cell, ESA } \\
\text { Coulochem II EC }\end{array}$ & $\begin{array}{l}34 \pm 2.3(\mathrm{SD}) \\
25.1 \pm 0.34 \\
(\mathrm{SD}) ; \text { mean } \\
30.0\end{array}$ \\
\hline [22] & Commercial & 6 & $\begin{array}{c}250 \times 4.6 \mathrm{~mm} \text { id } \\
5 \mu \mathrm{m}, \text { ODS-Hypersil }\end{array}$ & $\begin{array}{c}\mathrm{CH}_{2} \mathrm{Cl}_{2} 200 \mathrm{~mL}+\mathrm{CH}_{3} \mathrm{OH} \\
800 \mathrm{~mL}+5 \mathrm{~mL}(2 \mathrm{M} \mathrm{ZnCl}+1 \mathrm{M} \\
\mathrm{CH}_{3} \mathrm{COOH}+1 \mathrm{M} \mathrm{CH} \mathrm{CHOONa}_{3} / 1 \mathrm{~L} ; \\
1 \mathrm{~mL} \mathrm{~min}^{-1}\end{array}$ & $\begin{array}{l}\text { Postcolumn with dry } \\
\text { powder } \mathrm{Zn} \\
(20 \times 3.9 \mathrm{~mm})\end{array}$ & $\begin{array}{l}\text { Fluorescence Spectroflow } \\
980 \text { Applied Biosystems, } \\
\text { גex: } 248 \mathrm{~nm}, \lambda \text { em: } 418 \mathrm{~nm}\end{array}$ & $\begin{array}{c}37.2-82.1 \\
\text { mean } \\
55.5 \pm 6.3(\mathrm{SD})\end{array}$ \\
\hline [29] & Unspecified & 1 & $\begin{array}{c}250 \times 4.6 \mathrm{~mm} \text { id, } 3 \\
\text { and } 5 \mu \mathrm{m}, \mathrm{C} 30 \mathrm{YMC} \text {, } \\
\text { Wilmington }\end{array}$ & $\begin{array}{c}0.41 \mathrm{~g} \mathrm{CH}_{3} \mathrm{COONa}, 1.37 \mathrm{~g} \mathrm{ZnCl}_{2}, 0.30 \mathrm{~g} \\
\mathrm{CH}_{3} \mathrm{COOH}, 920 \mathrm{~mL} \mathrm{CH} \mathrm{CH}_{3} \mathrm{OH}, 80 \mathrm{~mL} \\
\mathrm{CH}_{2} \mathrm{Cl}_{2} ; 1-1.5 \mathrm{~mL} \mathrm{~min}{ }^{-1} \text {; grdient flow }\end{array}$ & $\begin{array}{l}\text { Postcolumn with dry } \\
\text { powder } \mathrm{Zn} \\
(20 \times 4.0 \mathrm{~mm})\end{array}$ & $\begin{array}{l}\text { Fluorescence RF-2000, } \\
\text { Dionex, } \lambda x .: 243 \mathrm{~nm}, \lambda \text { em: } \\
430 \mathrm{~nm}\end{array}$ & $\begin{array}{c}\text { E: 80.9; Z: 12.8; } \\
\sum 93.7\end{array}$ \\
\hline [36] & Commercial & 1 & $\begin{array}{c}250 \times 4.6 \mathrm{~mm} \text { id, } 5 \mu \mathrm{m} \\
\text { ODS-Hypersil } \\
\text { Gynkotek, } 40^{\circ} \mathrm{C}\end{array}$ & 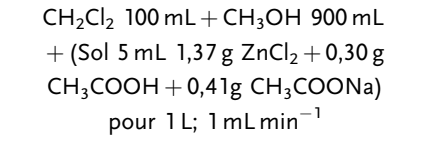 & $\begin{array}{l}\text { Postcolumn with dry } \\
\text { powder } \mathrm{Zn} \\
(20 \times 4.6 \mathrm{~mm})\end{array}$ & $\begin{array}{l}\text { Fluorescence spectrometer } \\
\text { F-1050, Merck, } \lambda \text { ex: } \\
243 \mathrm{~nm}, \lambda \text { em: } 430 \mathrm{~nm}\end{array}$ & $\begin{array}{c}16.5(16,5 \% \\
\mathrm{CV})\end{array}$ \\
\hline [37] & Commercial & 2 & $\begin{array}{l}300 \times 3.9 \mathrm{~mm} \text { id, } \\
10 \mu \mathrm{m}, \\
\mathrm{C} 18 \mu \text {-Bondapak, } \\
\text { Millipore, } 20^{\circ} \mathrm{C}\end{array}$ & $\begin{array}{c}\mathrm{CH}_{3} \mathrm{CN}, \mathrm{CH}_{2} \mathrm{Cl}_{2}, \mathrm{CH}_{3} \mathrm{OH}, 60 / 20 / 20 \\
(\mathrm{v} / \mathrm{v} / \mathrm{v}) ; 1 \mathrm{~mL} \mathrm{~min}{ }^{-1}\end{array}$ & no & $\begin{array}{l}\text { UV-Vis, Waters } 470 \text {, } \\
\text { Millipore, } \lambda: 248 \mathrm{~nm}\end{array}$ & $\begin{array}{c}12.7 ; 18.9 ; \\
\text { mean } \\
15.8 \pm 4.4(S D)\end{array}$ \\
\hline [38] & $\begin{array}{l}\text { Tunisie } \\
\text { Virgin } \\
\text { Chemlali } \\
\text { Virgin } \\
\text { Chétoui }\end{array}$ & $\begin{array}{l}21 \\
20\end{array}$ & $\begin{array}{l}250 \times 4.6 \mathrm{~mm} \text { id, } \\
4 \mu \mathrm{m}, \mathrm{C} 18 \text { Hypersil }\end{array}$ & $\begin{array}{c}\mathrm{CH}_{3} \mathrm{OH}, \underset{\mathrm{CH}}{\mathrm{CH}_{3} \mathrm{CN}, 95 / 5(\mathrm{v} / \mathrm{v})} ; \\
1 \mathrm{~mL} \mathrm{~min}^{-1}\end{array}$ & No & $\begin{array}{c}\text { UV-Vis, Agilent } \\
\text { Technologies, } \lambda: 292 \mathrm{~nm}\end{array}$ & $\begin{array}{l}30.0 \pm 5(\mathrm{SD}) \\
40.0 \pm 4(\mathrm{SD})\end{array}$ \\
\hline [39] & $\begin{array}{l}\text { Commercial } \\
\text { refined }\end{array}$ & 14 & $\begin{array}{c}200 \times 2.1 \mathrm{~mm}, 1.9 \mu \mathrm{m}, \\
\text { Hypersil GOLDTM } \\
\text { silica }\end{array}$ & $\begin{array}{c}\text { Solvent } \mathrm{A}: \mathrm{n}-\mathrm{C}_{6} \mathrm{H}_{14} \text { Solvent } \mathrm{B} \text { : } \\
\text { 1,4-dioxane, } \mathrm{CH}_{3} \mathrm{COOH} \\
0,01 \% \mathrm{v} / \mathrm{v} \text {, gradient }\end{array}$ & No & $\begin{array}{c}\text { Xevo TS-Q triple } \\
\text { quadrupole tandem MS } \\
\text { (APCI) }\end{array}$ & $\begin{array}{c}\text { Mean } 100(S D \\
100)\end{array}$ \\
\hline
\end{tabular}

$\mathrm{N}$, sample number; Phylloquinone content $\left(\mu \mathrm{g} 100 \mathrm{~g}^{-1}\right.$ or $\left.{ }^{*} \mu \mathrm{g} 100 \mathrm{~mL}^{-1}\right)$.

samples, two authors used an electrochemical detection in combination with HPLC. ${ }^{[10,19]}$ Nowadays, fluorescence technique was the most used detection for PH analysis. However, $\mathrm{PH}$ and its homologues did not show native fluorescence and had to be converted to the corresponding fluorescing hydroquinone with the help of electrochemical or chemical postcolumn reduction. The $\mathrm{PH}$ derived product obtained was phyllohydroquinone. In the case of electrochemical reduction, mobile phase was composed with an electrolyte $\left(\mathrm{NaClO}_{4}\right.$ aqueous solutions) and water-miscible organic solvents. ${ }^{[1,42]}$ The chemical reduction was performed with a solid phase reactor (placed between chromatographic column and fluorimeter): often full of dry powder zinc and sometimes using platinum catalyst. It required a mixture of methanol and 


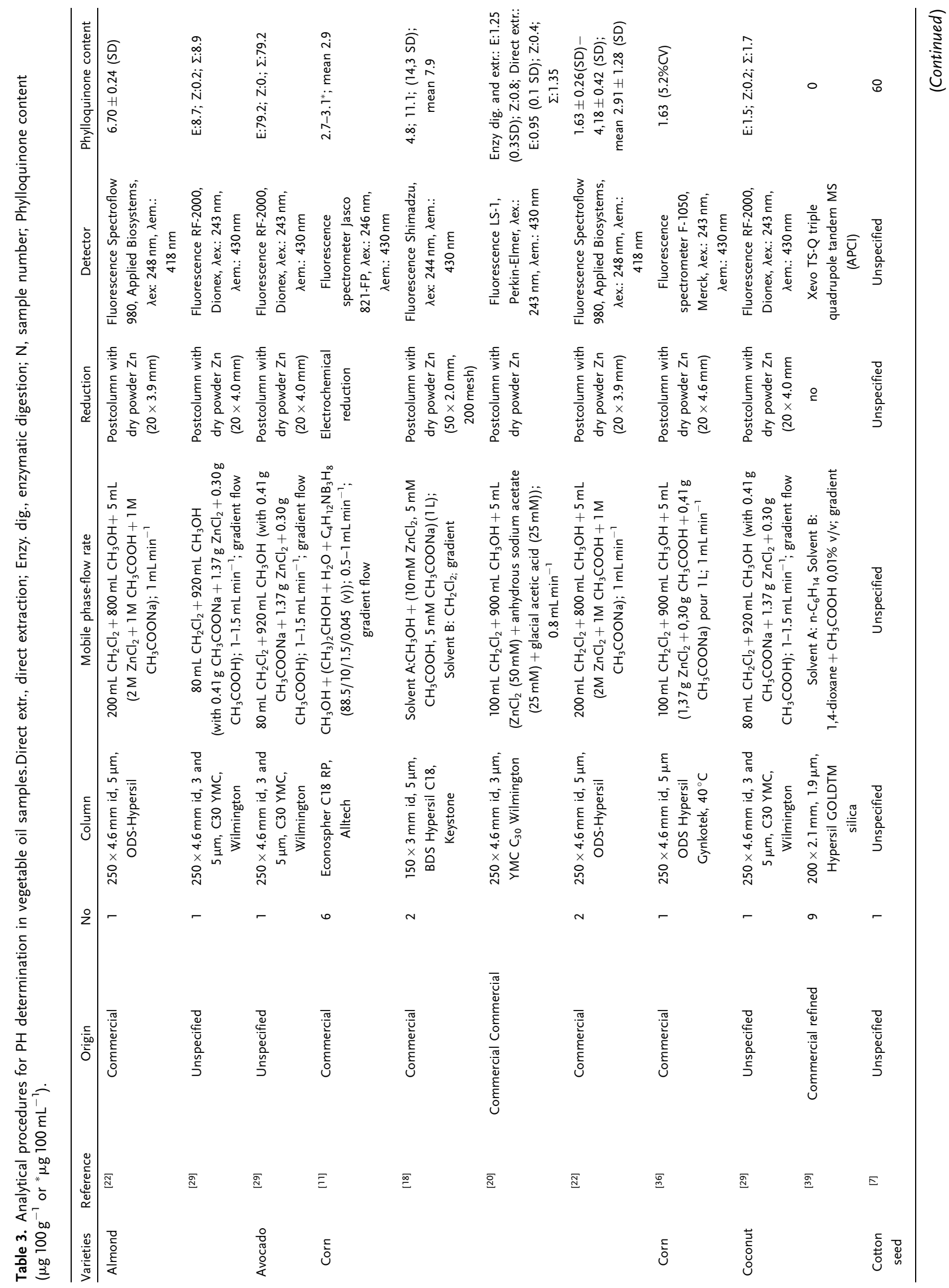




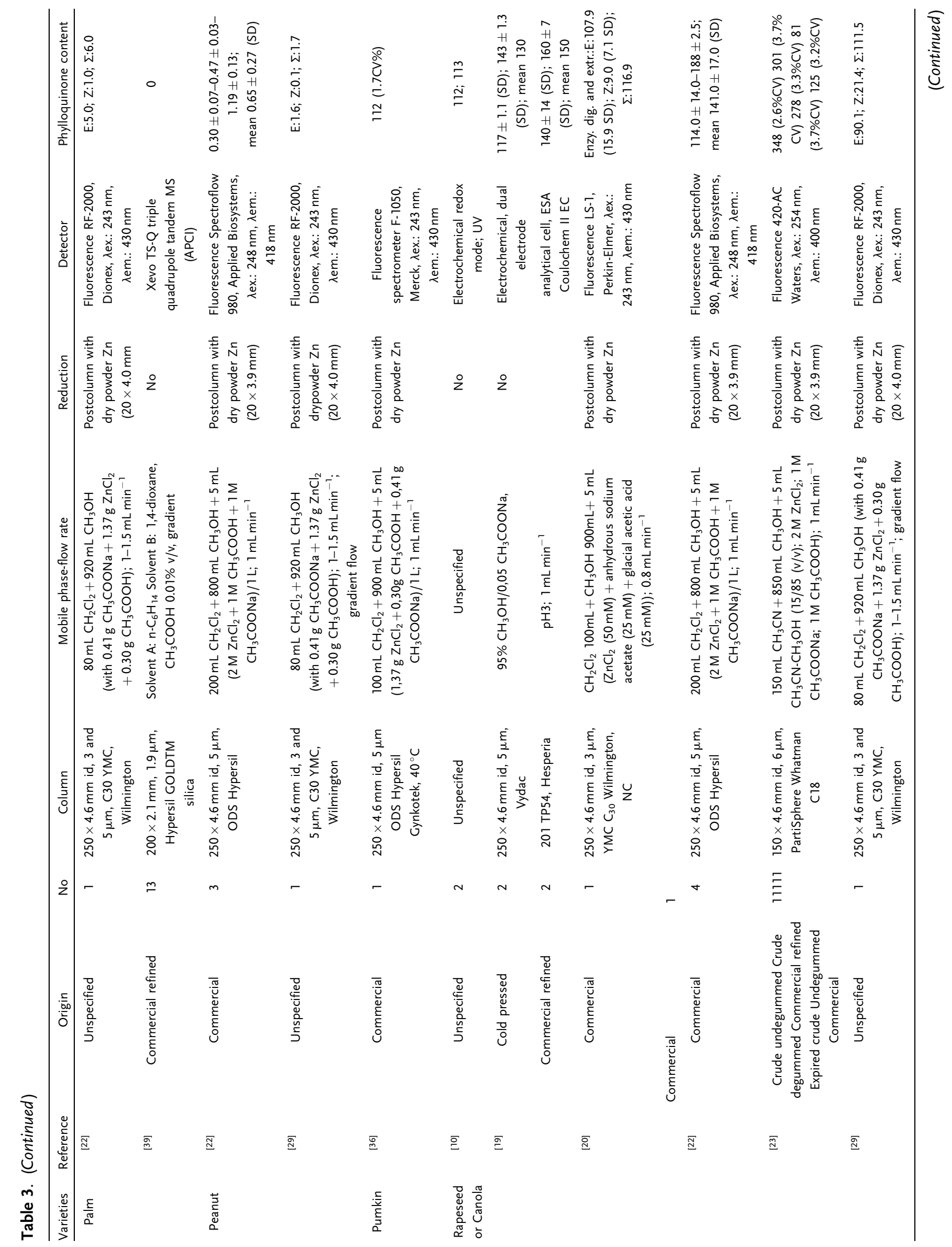




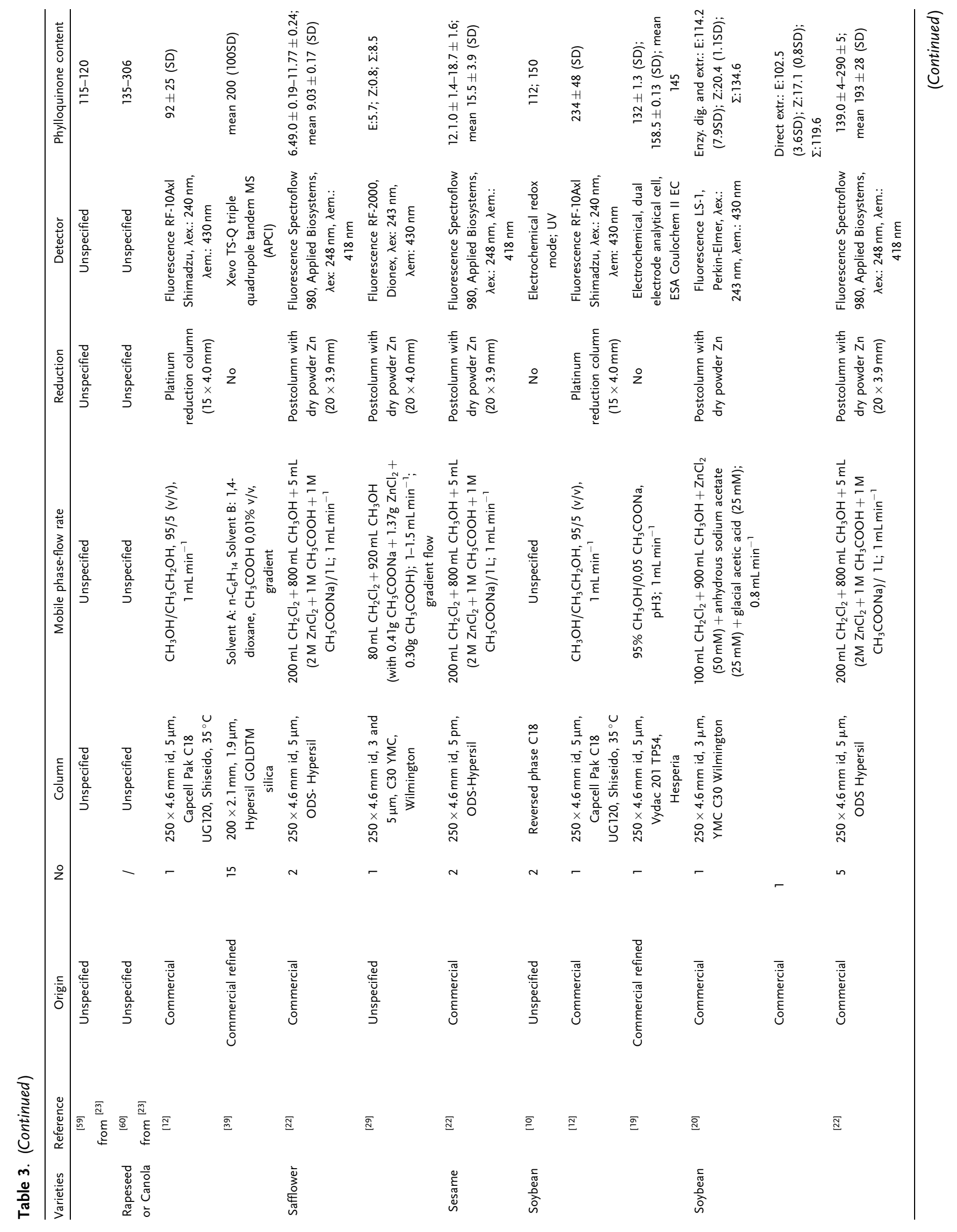




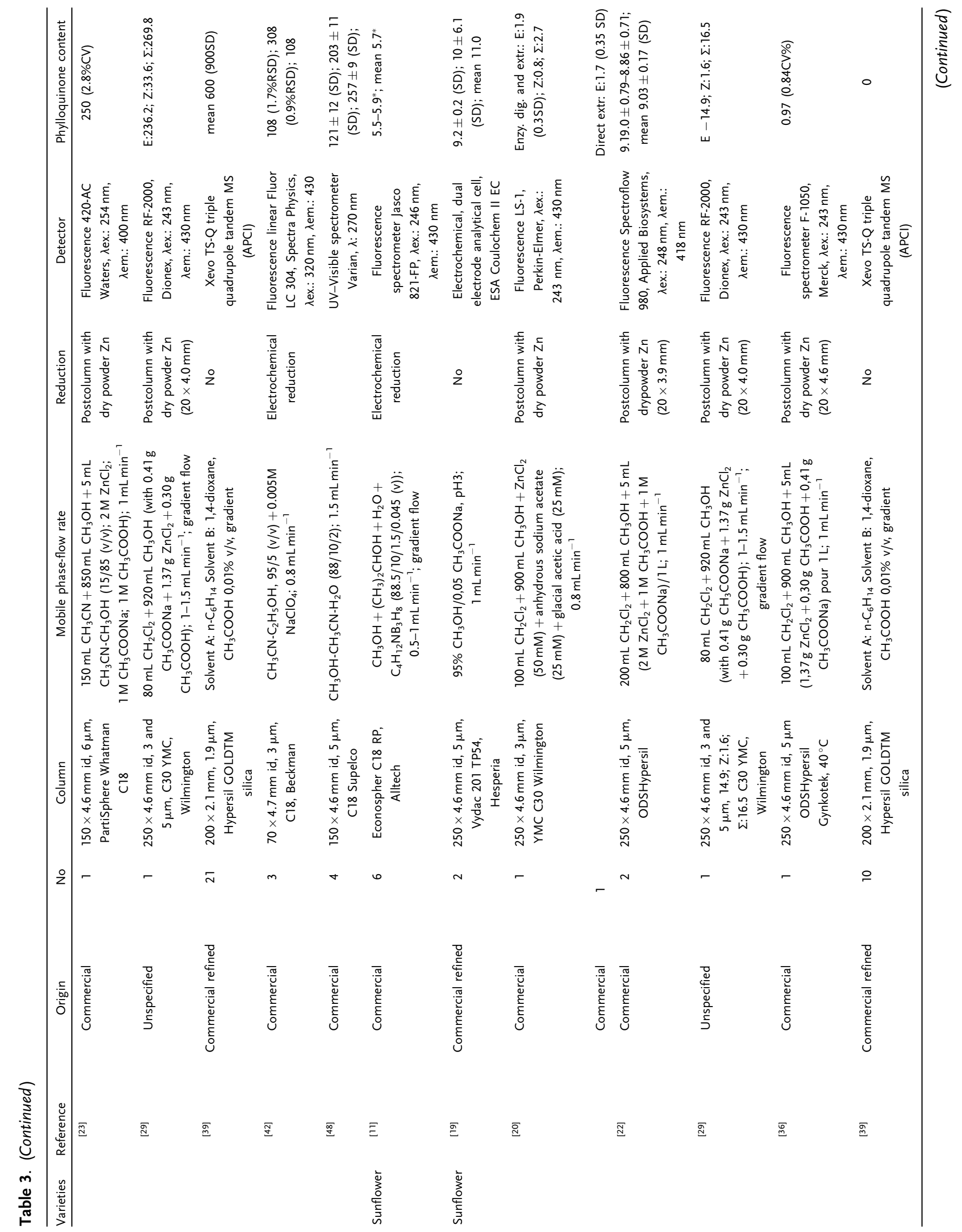


dichloromethane in which are added zinc chloride, sodium acetate, and acetic acid to optimize the reduction efficiency and the hydrogen gas generation for quinone reduction. The excitation wavelengths were often comprised between 240 and $248 \mathrm{~nm}$; authors used an excitation at $254 \mathrm{~nm}^{[23]}$ or worked at $320 \mathrm{~nm} \cdot{ }^{[42]}$ The fluorescence emission was measured between 400 and $430 \mathrm{~nm}$. Gao and $\mathrm{Ackman}^{[23]}$ tested the repeatability of $\mathrm{PH}$ peak height with this derivatization technique and reported that the capacity of a packed column for reduction was excellent ( $>100$ HPLC injections) under their analytical conditions. It was found that the reduction yield of $\mathrm{PH}$ was $95 \%$ with zinc reduction compared to $60 \%$ for electrochemical reduction. ${ }^{[57]}$ Only one publication reported the use of mass spectrometry detection for the PH quantification in oils using a TS-Q triple quadrupole instrument equipped with an atmospheric pressure chemical ionization probe in positive mode. ${ }^{[39]}$

\section{Phylloquinone Content in Olive and Vegetable Oils}

Table 2 and 3 grouped all PH content values extracted from literature and measured in olive oils and in 14 vegetable oils used for human consummation and in food industry. In most works, $\mathrm{PH}$ content was the sum of $\mathrm{E}$ and $\mathrm{Z}$ isomers content because of the used of a no selective stationary phase (C18). A C30 stationary phase enabled the separation of $\mathrm{E}$ and $\mathrm{Z}$ isomers of $\mathrm{PH}$ in vegetable oils. ${ }^{[20,29]}$ In these conditions, $\mathrm{E}$ isomer content was always superior to $\mathrm{Z}$ isomer proportion.

$\mathrm{PH}$ content of olive oils reported in the literature ranged from 12 to $100 \mu \mathrm{g} 100 \mathrm{~g}^{-1}$ in according to the HPLC detection used and the sampling itself for which little information was done, namely varietal origin, method, and date of manufacture, storage conditions. Furthermore, sample preparation before chemical analyses and detection mode were important elements to take into account in result interpretation. With UV detection, results obtained by two authors ${ }^{[37,38]}$ showed that the PH content was in the ratio of one to two because of the nature of sampling (one was commercial and the other grouped two certified cultivars), the difference in the sample preparation (hot saponification or semi preparative HPLC), the divergence in the detection wavelength (at $248 \mathrm{~nm}$, the highest absorbance of $\mathrm{PH}$ or at $292 \mathrm{~nm}$, a common wavelength for fat soluble vitamins but a low absorbance of $\mathrm{PH}{ }^{[58]}$ with the incertitude of a no specific $\mathrm{PH}$ detection in these analysis conditions). The same coefficient variation $(\mathrm{CV})$ was obtained between the two authors using an UV detector. Fluorescence technique conduced also to $\mathrm{PH}$ content with a wide range of variations $\left(37-82 \mu \mathrm{g} 100 \mathrm{~g}^{-1}\right)$, which could be attributed to the same factors cited before and to the derivative technique used to obtain fluorescent compounds. The standard deviation (SD) was of the order of four on average except for two references ${ }^{[12,18]}$ where it was around 11 and 14 for one or two samples analyzed. Similar variation ranges for PH contents were obtained with the other detections (electrochemical and MS) but the standard deviation was abnormally high for HPLC-MS analyses (equal to 100 from Nagy et al. ${ }^{[39]}$ ). It was noted that an extra virgin olive oil seemed to be richer in vitamin $\mathrm{K}$ than refined or cheaper oil. ${ }^{[10,19]}$ But this comparison should be interpreted with caution because it was not the same sample 


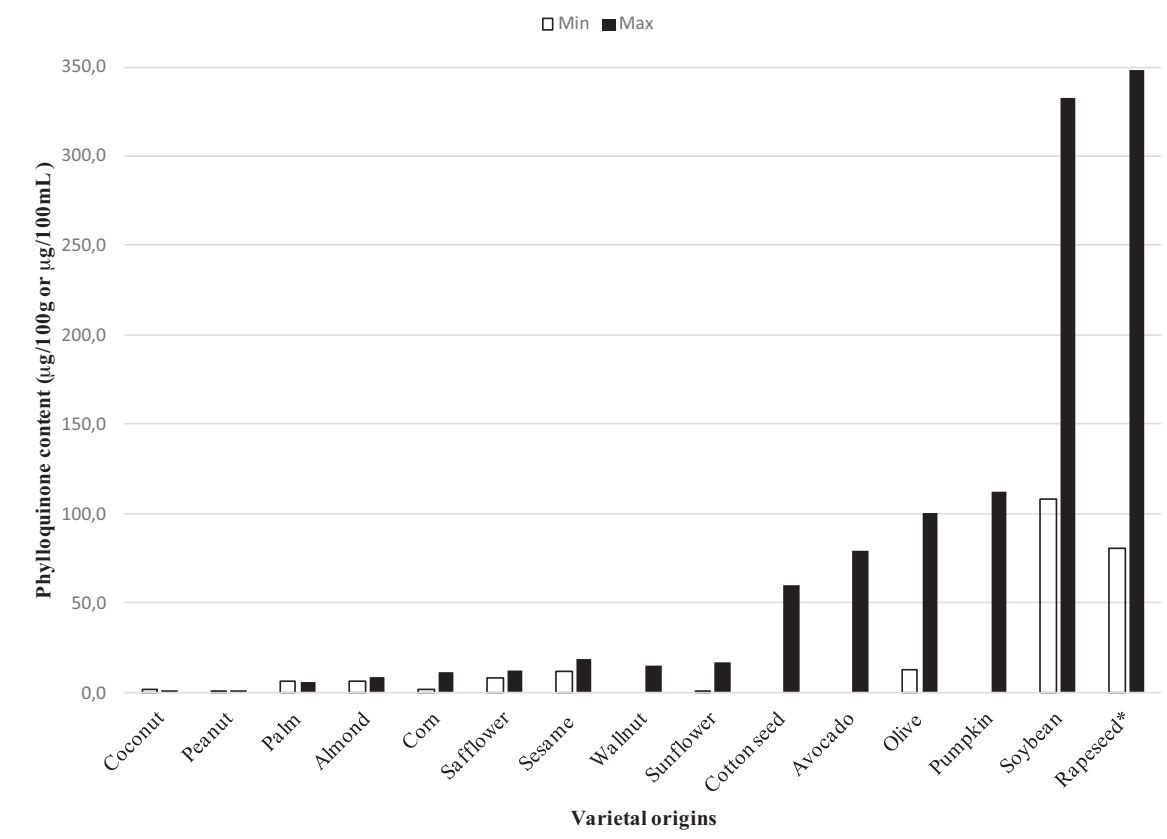

*Rapeseed or Canola

Figure 4. Phylloquinone contents of various vegetable oils.

perhaps. Only, Woollard et al. ${ }^{[29]}$ quantified E and Z isomers in olive oils and found that E isomer was $86.3 \%$ of the sum of the two isomers.

$\mathrm{PH}$ content of the other vegetable oils reported in the literature was a function of varietal origin of oils. Vegetable oils data were reported in function of their commercial importance: corn, rapeseed (canola), soybean, and sunflower oils are the most studied. To compare them, the $\mathrm{PH}$ extreme values of all oil samples (extracted from Table 2 and 3) were reported in the Figure 4. Despite of the different analytical techniques used to quantify phylloquinone, two oil groups appeared: one describing oils having a maximum PH content superior at $60 \mu \mathrm{g} / 100 \mathrm{~g}$ (avocado, cottonseed, olive, pumpkin, rapeseed, and soybean) and one other closing the oils with a maximum value inferior to $20 \mu \mathrm{g} / 100 \mathrm{~g}$. Here the same problematic of oil history resurfaced because little information was provided on oil sampling. Studied samples were, in the majority of cases, commercial oils that supposed undergone a refining before their marketing. Only one study ${ }^{[23]}$ reported a decrease of $\mathrm{PH}$ content after a transformation process (degumming, refining, bleaching, winterizing, deodorizing) of canola oil (fresh or expired) and stored in plastic, metal, or glass bottles but it was not about the same crude oil used every time. Opposite results were obtained by Piironen et al. ${ }^{[19]}$ who analyzed two series of Finnish turnip rapeseed oil (16 refined and 14 cold pressed oils) without the refined and cold pressed oils being the same origin. Nagy et al. ${ }^{[39]}$ did not found $\mathrm{PH}$ in vegetable oils as coconut, palm, and sunflower and they made the assumption that the $\mathrm{PH}$ absence was due to the refining process. Nevertheless, other authors who analyzed refined oil from the same varietal origin did not obtain a zero value for PH content. Cook et al. ${ }^{[20]}$ compared for the same oil (corn or canola) the impact of the sample preparation (enzymatic digestion/extraction or direct extraction). Their results showed little significant difference between the two methods. The authors concluded that both sample preparations led to the same precision. In the case of olive oil, only one article published $\mathrm{PH}$ values of $\mathrm{E}$ and $\mathrm{Z}$ isomers; the content of two $\mathrm{E}$ and $\mathrm{Z}$ isomers was 80.9 and $12.8 \mu \mathrm{g} 100 \mathrm{~g}^{-1}$, respectively. ${ }^{[29]}$ The others works mentioned only the total $\mathrm{PH}$ content because the used stationary phase did not separate them. A high standard deviation was often reported with the mean value of $\mathrm{PH}$ content because of the small number of analyzed samples or a large variability of $\mathrm{PH}$ content of the sampling that it stated by one author working on numerous oil samples (from 9 to 21 according the varietal origin). ${ }^{[39]}$ Very few authors provided $\mathrm{PH}$ detection limit that varied between 0.01 and $0.5 \mu \mathrm{g} 100 \mathrm{~g}^{-1[9,42]}$ for fluorescence detection. Test on linearity and sensitivity of LC-dual-electrode or LC-Fluorescence revealed that the minimum detectable of $\mathrm{PH}$ amount was $20-50 \mathrm{pg}$ or $2-10 \mathrm{pg}$, respectively. ${ }^{[19,29]}$

\section{Conclusion}

Bibliometric study showed that few studies related to the determination of phylloquinone content of vegetable oils and in particular that of olive oils. The published quantification methods were mainly developed for analyzing vegetable, food matrices, and plasma. It appeared that the analytical technique most used to quantify the phylloquinone in vegetable oils was HPLC equipped with a reduction post column coupled with fluorescence detection. Over time, the sample preparation (the most important step of analytic process) has been simplified but deficiencies continued to exist for the determination of $\mathrm{PH}$ and internal standards recoveries. In addition, the validation of the 
analytical technique was rarely instituted. Most published analyses only measured total vitamin $\mathrm{K}$ on a C18 stationary phase but a $\mathrm{C} 30$ stationary phase allowed the separation of $\mathrm{E}$ and $\mathrm{Z} \mathrm{PH}$ isomers, to obtain the true nutritional value of $\mathrm{PH}$. This separation is important because only $\mathrm{E}$ isomer is known to have a biological activity. However, the existence of $\mathrm{E}$ and $\mathrm{Z}$ isomers in native olive and vegetable oils remained unclear. Is that the presence of $\mathrm{Z}$ isomer could be natural or due to manufacture process of oils (refining, ...)? No comparative study was done on the same olive oil sampling: virgin and refined. As well as rapeseed (canola) and soybean oils, olive oil was part of interesting oils for their significant $\mathrm{PH}$ content. Nevertheless, the variation range of $\mathrm{PH}$ content in olive oils was large and was due to the lack of information about the sampling itself: varietal origin, quality, manufacturing process, manufacture date, nature of package for its storage, storage conditions, ageing. All these parameters having a great influence on its composition would be considered in future studies.

\section{Abbreviations}

CA, chemical abstract; EO, edible oil; GS, google scholar; IUPAC, International Union of Pure and Applied Chemistry; MK-n, menaquinones; N, sample number; OO, olive oil; $\mathrm{PH}$, phylloquinone; SPE, solid phase extraction; TLC, thin layer chromatography; VK, vitamin K; VK1, vitamin K1; VO, vegetable oil; WoS, Web of Science.

\section{Conflict of Interest}

The authors declare no conflict of interest.

\section{Keywords}

cis- trans-isomers, HPLC, olive oils, phylloquinone, Vitamin $\mathrm{K}_{1}$, Vegetable oils

[1] G. Fauler, W. Muntean, H. J. Leis, in: De Leenheer, A. P., Lambert, W. E., Bocxlaer, J. F. (Eds.), Modern Chromatographic Analysis of Vitamins, Vitamin K, Marcel Dekker, New York 2000, pp. 240.

[2] M. J. Shearer, P. Newman, Thromb. Haemost. 2008, 100, 530.

[3] S. L. Booth, Food Nutr. Res. 2012, 56, 5505.

[4] J. W. J. Beulens, S. L. Booth, E. G. H. M. van den Heuvel, E. Stoecklin, A. Baka, C. Vermeer, Br. J. Nutr. 2013, 110, 1357.

[5] R. R. Eitenmiller, L. Ye, Jr. W. O. Landen, Vitamins Analysis for the Health and Food Sciences, Vitamin K. CRC Press, New York 2008, pp. 193.

[6] E. A. Nutescu, N. L. Shapiro, S. Ibrahim, P. West, Expert Opin. Drug Saf. 2006, 5, 433.

[7] S. L. Booth, J. W. Suttie, J. Nutr. 1998, 125, 785.

[8] S. L. Booth, J. A. Sadowski, J. L. Weihrauch, G. Ferland, J. Food Comp. Anal. 1993, 6, 109.

[9] S. L. Booth, J. A. Sadowski, J. A. T. Pennington, J. Agric. Food Chem. 1995, 43, 1574.
[10] C. Bolton-Smith, J. G. Rosemary, R. J. G. Price, T. Steven, S. T. Fenton, D. J. Harrington, M. J. Shearer, Br. J. Nutr. 2000, 83, 389.

[11] L. J. Schurgers, C. Vermeer, Haemostasis 2000, 30, 298.

[12] M Kamao, Y. Suhara, N. Tsugawa, M. Uwano, N. Yamaguchi, K. Uenishi, H. Ischida, S. Sasaki, T. Okano, J. Nutr. Sci. Vitaminol. 2007, 53, 464.

[13] G. Ferland, J. A. Sadowski, J. Agric. Food Chem. 1992, 40, 1874.

[14] M. Damon, N. Z. Zhang, D. B. Haytowitz, S. L. Booth, J. Food Comp. Anal. 2005, 18, 751.

[15] T Sakano, S Notsumoto, T Nagaoka, A Morimoto, K Fujimoto, S Masuda, Y Suzuki, K. Hirauchi, Vitamins (Japan) 1988, 62, 393.

[16] N. Presse, S. Potvin, B. Bertrand, M. S. Calvo, G. Ferland, J. Food Comp. Anal. 2015, 41, 15.

[17] S. L. Booth, H. T. Madabushi, K. W. Davidson, J. A. Sadowski, J. Am. Die. Assoc. 1995, 95, 82.

[18] J. W. Peterson, K. L. Muzzey, D. Haytowitz, J. Exler, L. Lamar, S. L. Booth, JAOCS 2002, 79, 641.

[19] V. Piironen, T. Koivu, O. Tammisalo, P. Mattila, Food Chem. 1997, 59, 473.

[20] K. K. Cook, G. V. Mitchell, E. Grundel, J. I. Rader, Food Chem. 1999, 67, 79.

[21] T. Koivu, V. Piironen, A. M. Lampi, P. Mattila, Food Chem. 1999, 64, 411.

[22] G. Ferland, J. A. Sadowski, J. Agric. Food. Chem. 1992b, 40, 1869.

[23] Z. H. Gao, R. G. Ackman, Food Res. Int. 1995, 28, 61.

[24] T. Koivu-Tikkanen, Determination of phylloquinone and manaquinones in foods by HPLC. Academic dissertation, 2001, University of Helsinki, Finland.

[25] M. León-Camacho, M. T. Morales, R. Aparicio, in: Aparicio R., Harwood J. (Eds.), Handbook of Olive Oil, Analysis and Properties, 2nd Edn. Springer Science+Business Media, New York 2013, pp. 163-217.

[26] S. Laroussi-Mezghani, Y. Le Dréau, J. Molinet, M. Hammami, N. Grati-Kamoun, J. Artaud, Eur. Food Res. Tech. 2016, 242, 1087.

[27] J. W. Suttie, Vitamin K in Heath and Disease. CRC Press, New York 2009.

[28] D. B. Parrish, Crit. Rev. Food Sci. Nutr. 1980, 13, 337.

[29] D. C. Woollard, H. E. Indyk, H. Y. Fong, K. K. Cook, J. AOAC Int. 2002, $85,682$.

[30] M. J. Shearer, P. Newman, Schattauer 2008, 530.

[31] H. H. W. Thijssen, L. M. T. Vervoort, L. J. Schurgers, M. J. Shearer, Br. J. Nutr. 2006, 95, 260.

[32] G. H. Dialameh, W. V. Taggart, J. T. Matschiner, R. E. Olson, Int. J. Vitam. Nutr. Res. 1971, 41, 391.

[33] M. Kamao, Y. Suhara, N. Tsugawa, T. Okano, J. Chromatogr. B 2005, 816, 41.

[34] A.-W. Harzing, S. Alakangas, Scientometrics 2016, 106, 787.

[35] M. Zitt, A. Lahatte, D. Vallée, M.-L. Taillibert, E. Bassecoulard, 2010, Note sur la comparaison Web of Science-ACM Guide pour la couverture bibliométrique de l'informatique. Convention $n^{\circ} 09 \mathrm{G}$ 623 avec le ministère de la Recherche et de l'Enseignement supérieur-DGRI. www.obsost.fr/sites/default/files/Etude_INFO_ rapportfinal_VF.pdf

[36] E. Jakob, I. Elmadfa, Food Chem. 1996, 56, 87.

[37] S. Otles, O. Cagindi, Food Chem. 2007, 100, 1220.

[38] N. Zakhama, I. Bettaieb, W. A. Wannes, B. Marzouk, Riv. Ital. Sostanze Grasse 2011, Vol. LXXXVIII, 240.

[39] K. Nagy, A. L. Kerrihard, M. Beggio, B. D. Craft, R. B. Pegg, Food Res. Int. 2016, 84, 26.

[40] P. B. Ottaway, in: Henry, C. J. K., Chapman C. (Eds.), The Nutrition Handbook for Food Processors, CRC Press, Boca Raton, FL 2002, pp. 247-264.

[41] C. Fanali, G. D'Orazio, S. Fanali, A. Gentili, Trends in Anal. Chem. 2017, 87, 82.

[42] F. Moussa, F. Depasse, V. Lompret, J.-Y. Hautem, J.-P. Girardet, J.L. Fontaine, P. Aymard, J. Chromatogr. A 1994, 664, 189.

[43] S. M. Hwang, J. Assoc. Off. Anal. Chem. 1985, 68, 684. 
[44] H. Indyk, Milchwissenschaft 1988, 43, 503.

[45] A. Gentili, F. Caretti, S. Bellante, S. Ventura, S. Canepari, R. Curini, J. Agri. Food Chem. 2012, 61, 1628.

[46] A. Gentili, A. Miccheli, P. Tomai, M. E. Baldassarre, R. Curini, V. Pérez-Fernández, J. Food Comp. Anal. 2016, 47, 21.

[47] E. Jakob, I. Elmadfa, Food Chem. 2000, 68, 219.

[48] F. Zonta, B. Stancher, J. Chromatogr. 1985, 329, 251.

[49] P. M. Panagiotopoulou, M. Tsimidou, Grasas Aceites 2002, 53, 84.

[50] H. Kim, Y. Chol, J. Sung, Y. Kim, H. S. Jeong, J. Lee, Food Sci. Biotechnol. 2015, 24, 1603.

[51] A. Osman, U. Hannestad, Rapid Commun. Mass Spectrom. 2008, 22, 3861.

[52] J. T. Matschinter, R. G. Bell, J. Nutr. 1972, 102, 625.
[53] G. Dahl, Eur. J. Lipid Sci. Tech. 1987, 2, 60.

[54] M. Careri, A. Mangia, P. Manini, N. Taboni, Fresenius J. Anal. Chem. 1996, 355, 48

[55] Y. Haroon, C. A. W. Schubert, P. V. Hauschka, J. Chromatogr. Sci. $1984,22,89$

[56] J. P. Hart, M. J. Shearer, P. T. McCarthy, Analyst 1985, 110, 1181.

[57] Y. Haroon, D. S. Bacon, J. A. Sadowski, J. Chromatogr. 1987, 384, 383.

[58] D. T. Ewing, F. S. Tomkins, O. Kamm, J. Biol. Chem. 1943, 147, 233.

[59] G. Ferland, K. W. Davidson, E. N. Candela, J. A. Sadowski, The FASEB J. 1989, 3, A662, (from [23]).

[60] R. J. Ragan, C. T. Seipelt, T. J. Lukacs, S. R. Behr, B. S. Travis, Canola oil: an unsuspected source of vitamin KI. Paper in the 83rd Annual AOCS-ISF meeting 1992, Toronto, from [23]). 